\title{
Relationship between psychological well-being and altruistic behaviour in students during the COVID-19 pandemic
}

\author{
Thrisia Febrianti $^{1}$, Mungin Eddy Wibowo ${ }^{2}$, Urotul Aliyah ${ }^{2}$, Susilawati $^{3}$ \\ ${ }^{1}$ Universitas Islam As Syafi'iyah \\ ${ }^{2}$ Universitas Negeri Semarang \\ ${ }^{3}$ Universitas Nahdlatul Ulama Al \\ thrisiafs3@students.unnes.ac.id
}

Submitted: 21-06-2020, Revised: 02-10-2021, Accepted: 14-11-2021

\begin{abstract}
This study aims to determine the relationship between Psychological well-being and students' altruistic behaviour. The psychological well-being of students is very important to note, this is because it is related to the mood of satisfaction and happiness, especially for students. Altruistic behaviour is a person's volunteerism in helping and helping others. This research was conducted during the COVID-19 pandemic to find out whether there was a relationship between Psychological well-being and Altruistic behaviour during the COVID-19 pandemic. This study involved 175 high school students in Semarang City who were taken using the conventional technique. The instruments used in this study were the Psychological Well Being Scale and the Altruistic Behaviour Scale. This research is a quantitative correlation study and the data were analyzed using descriptive analysis with the help of IBM SPSS for Windows to describe the relationship of Psychological wellbeing with Altruistic behaviour. The results showed that the overall significance value $($ Sig $=0.77>0.05)$ so that there was no significant correlation between Psychological Well Being and Altruistic Behaviour.
\end{abstract}

Keywords: Altruistic Behaviour; Psychological Well-Being

\section{Introduction}

The COVID-19 pandemic greatly affects a person's level of well-being in living their daily lives. The first Covid-19 outbreak appeared in Wuhan, China (Shi, et al., 2020). Currently, COVID-19 is spreading throughout the world, including in Indonesia. Indonesia has issued a disaster emergency status from 29 February 2020 to 29 May 2020 (Aida, 2020). On July 9, 2020, the Ministry of Health reported that there were 70,736 cases of Covid-19 in Indonesia with 3,417 deaths (CFR 4.8\%) (Pemerintah Republik Indonesia, 2019). The Covid19 pandemic event has an impact on all fields in Indonesia, including in the field of education, this is because Covid-19 has infected hundreds of thousands and even millions of people in Indonesia. The action taken by the Indonesian government is to issue Circular Letter Number 4 of 2020 concerning the Implementation of Educational Policy for the Emergency Period for the Spread of Coronavirus Disease (Covid-19). The Elementary School began to change its strategy, namely that all students study from home (Pemerintah Republik Indonesia, 2019)

Covid-19 has brought changes in the realm of education, where all schools have switched to online classes. Online classes are teaching and learning activities using ICTbased internet networks (Andiarna \& Kusumawati, 2020). Online learning has been carried out in various forms, ranging from giving assignments through the WhatsApp Group application, video conferencing, google forms, or through special educational applications available (Handarini \& Wulandari, 2020)

Changes in online teaching methods affect the psychological condition of students in carrying out activities as students, because Indonesian students are accustomed to the face-toface system directly, and it was found that $28.3 \%$ of students experienced learning stress (Zalsabella et al., 2020). Another study also revealed that $66.97 \%$ of students admitted that learning during the COVID-19 pandemic was considered inactive (Hamdani \& Priatna, 2020). 
The psychological well-being of students has a close relationship with mood, satisfaction and happiness. Psychological well-being is so prominent in society and culture, that most people even pursue psychological well-being as a life goal (Isgör, 2016). Several psychology figures have discussed the main roots of the theory of well being. According to Ryff (1989) psychological well-being is the integration of mental health, clinical, and life span development theories that lead to the functioning of positive psychological functioning.

A study revealed that Psychological well-being has a positive and significant effect on Self-efficacy and Positive Thinking, where Self-efficacy and Positive Thinking can improve Psychological well-being in students, this research also suggests testing Psychological wellbeing associated with psychological aspects and different variables (Alkhatib, 2020). Psychological well-being, in general, cannot arise alone, because humans need the help of other humans, groups and positive environments in carrying out their daily lives, so that their welfare can be well maintained.

During the COVID-19 pandemic, all teaching and learning activities were carried out online, requiring educational institutions to innovate in the learning process, which previously took classes offline, but now they have switched to online classes. This condition disturbs the psychology of the community, thus encouraging the government and the public to pay attention to psychological well being (Sa'diyah, 2020). Another study revealed that the psychological well-being of high school/vocational high school students throughout South Sulawesi during online learning activities during the COVID-19 pandemic was in the moderate category (Aryani et al., 2020).

During the COVID-19 pandemic, the community needs to support and help each other in dealing with this difficult time. Altruistic behaviour is generally defined as any form of voluntary action that intends to help others without expecting anything in (Mackie et al., 2000). It is known that someone who performs altruistic behaviour means that in that person a sense of empathy has been embedded for others (Nurhidayati, 2012). Altruistic behaviour helps others achieve their goals, share valuable goodness with others, and inform others about things they need or want to know (Warneken \& Tomasello, 2009).

Altruistic behaviour is a person's willingness to help others (Permatahati, 2016). Altruistic behaviour is a very important positive behaviour, which in various studies shows the positive impact of altruistic behaviour by the needs of the person being helped and the perpetrator himself gets an internal reward for his actions. Strong feelings of altruistic behaviour provide valid evidence for the individual, so he must value the welfare of others (Batson et al., 1995). Much consistency shows that individual differences in altruistic behaviour can be measured directly by the altruism scale (Rushton et al., 1981).

As a social system, secondary school is an accumulation of interacting and plural social components and groups. Positive social interaction in high school can be interpreted as social relations between students that are dynamically and harmoniously intertwined (Desmita, 2009). Altruistic behaviour has a positive influence on one's psychological wellbeing (Because, Bhatta, Lovegreen, Kahana, \& Midlarsky, 2013). Meanwhile, another study revealed that altruistic behaviour did not affect the psychological well-being of the Hati Kita studio volunteers in Tulungagung Regency (Permatahati, 2016). The difference in the results of the two studies prompted researchers to examine the level of relationship between psychological well-being and altruistic behaviour in high school students in the city of Semarang during the COVID-19 pandemic.

\section{Methods}

This study uses a correlational quantitative design. Collecting data using research instruments, data analysis is quantitative with the aim of testing the established hypothesis 
(Sugiyono, 2015). The scale used is the scale adopted from the owner of the theory so it must have procedures and guidelines used in the process of adapting the scale in counseling assessment, while the flow used is as follows:

Figure 1. Scale Adaptation Flow (Lenz et al., 2017)

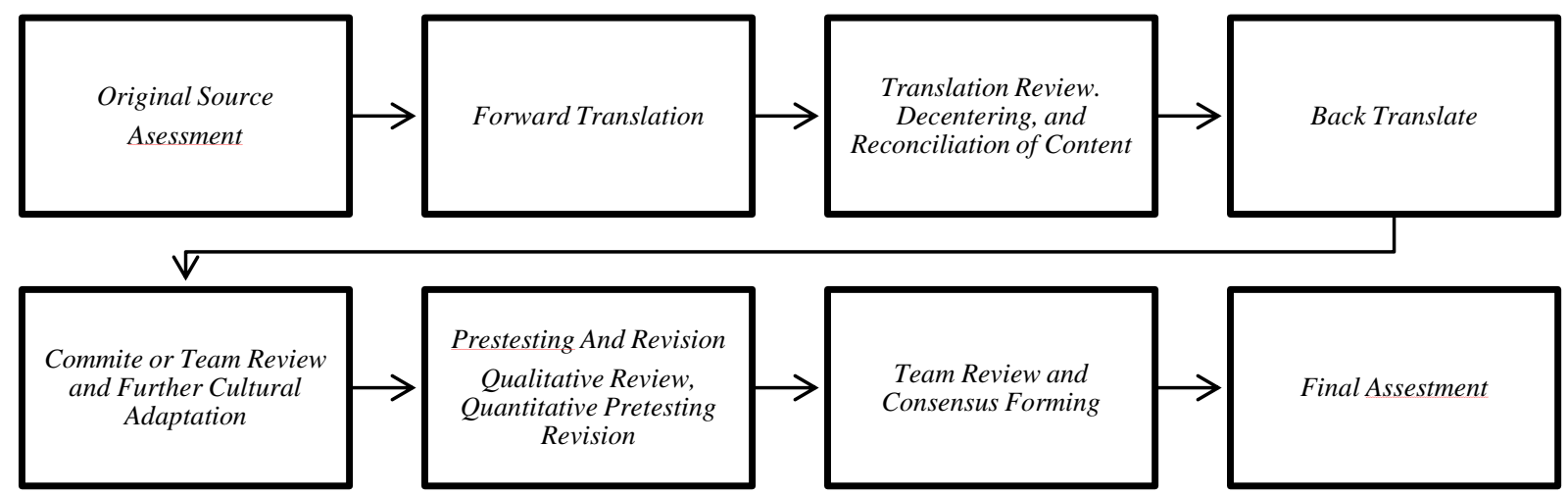

Data were collected using the Psychological Well Being Scale (Ryff, 1989), and the Altruistic Behaviour Scale (Myers, 1999), with the coefficient reliability level of each instrument Cronbach Alpha (0.90). The data analysis in this research is a correlation to determine the relationship between Psychological Well Being and Altruistic Behaviour. The population consists of objects and also subjects that have characteristics that match the criteria of the researcher who will later be studied and conclusions can be drawn (Sugiyono, 2015). The population in this study were all high school students in the city of Semarang. The sample of this study consisted of 175 high school students from State Senior High Schools in Semarang who had filled out the questionnaire that had been distributed via google.

\section{Results and Discussion}

The administration of the instrument was carried out by distributing the instrument to students assisted by a school counsellor. A total of 175 students have participated in this study.

Table 1. Summary Analysis of Pearson Correlations

\begin{tabular}{|c|c|c|}
\hline \multicolumn{3}{|c|}{ Analysis of Pearson Correlations } \\
\hline & Psychological Well Being & Altruistic Behaviour \\
\hline Psychological Well Being & Sig. & .778 \\
\hline Altruistic Behaviour & .778 & \\
\hline
\end{tabular}

The table results from this study indicate that the significance value ( $\mathrm{Sig}=0.77>$ 0.05) means that there is no significant correlation between Psychological Well Being and Altruistic Behaviour. So Psychological Well Being has no relationship or influence on Altruistic Behaviour in high school students in Semarang City. According to Ryff (1989) psychological well-being is a multidimensional measure of psychological development and mental health. During the COVID-19 pandemic, mental health has become the focus of attention, especially among students. The learning system that has changed has an impact on students, therefore students need to get support from various parties, especially support from 
their social environment. Individuals who receive social support have a higher level of psychological well-being (Wikanestri \& Prabowo, 2015)

Good social support is received when individuals are in a good environment and help each other. Altruistic behaviour refers to a type of selfless help based on a genuine desire to help others (Aronson et al., 2004). This study examines the relationship between psychological well-being and altruistic behaviour of students during the covid-19 pandemic, and the results of this study reveal that there is no significant relationship between psychological well-being and altruistic behaviour during the covid-19 pandemic. Therefore, this study answers that psychological well-being is not influenced by altruistic behaviour.

Previous research suggested testing the relationship between psychological well-being with different psychological aspects and variables (Alkhatib, 2020), in this study, it was found that psychological well-being and altruistic behaviour during the COVID-19 pandemic did not have a significant correlation. The results of this study require further investigation because the pandemic period of interaction between humans is very limited so that the social support provided is not felt.

This study only examines the relationship between Psychological well-being and altruistic behaviour, so it would be better if there was further research to determine the level of Psychological well-being and altruistic behaviour and efforts to improve these two variables. According to Capuzzi \& Stauffer (2016) group counselling is a dynamic interpersonal process centred on conscious thought and behaviour. So that in the future it can be considered to test whether group counselling can improve students' psychological wellbeing and altruistic behaviour.

\section{Conclusions and Suggestions}

This study looked at the relationship between psychological well-being and altruistic behaviour, and the result was that there was no significant relationship between the two variables. During a pandemic, help and support from others are needed in maintaining a person's psychological well-being, but this study did not find the effect of help, support or altruistic behaviour on a person's well-being. Further research needs to be done, to find out more deeply whether during the pandemic each individual had intense interactions with other individuals and gave each other reinforcement.

In addition, this research needs to be developed by taking into account the wider distribution of research respondents or at different levels of education. Consider the culture of the place to be studied, because culture will affect a person's nature and habits. Future research can also intervene to improve students' psychological well-being during a pandemic.

\section{References}

Aida, N. R. (2020). 15 negara yang berlakukan lockdown akibat virus corona. Diakses tanggal 17/11/2021.

Alkhatib, M. A. H. (2020). Investigate the relationship between psychological well-being, self-efficacy and positive thinking at prince sattam bin abdulaziz university. International Journal of Higher Education, 9(4), 138-152.

Andiarna, F., \& Kusumawati, E. (2020). Pengaruh pembelajaran daring terhadap stres akademik mahasiswa selama pandemi Covid-19. Jurnal Psikologi, 16(2), 139-149.

Aronson, E., Wilson, T. D., Akert, R. M., \& Fehr, B. (2004). Social psychology (2nd Canadian ed.). Toronto, ON, Canada: Pearson Education.

Aryani, F., Umar, N. F., \& Kasim, S. N. O. (2020). Psychological well-being of students in undergoing online learning during pandemi COVID-19. International Conference on Science and Advanced Technology (ICSAT). 
Batson, C. D., Klein, T. R., Highberger, L., \& Shaw, L. L. (1995). Immorality from empathyinduced altruism: When compassion and justice conflict. Journal of Personality and Social Psychology, 68(6), 1042.

Capuzzi, D., \& Stauffer, M. D. (2016). Counseling and psychotherapy: Theories and interventions. John Wiley \& Sons.

Desmita, D. (2009). Psikologi perkembangan peserta didik. Remaja Rosdakarya.

Hamdani, A. R., \& Priatna, A. (2020). Efektifitas implementasi pembelajaran daring (full online) dimasa pandemi Covid-19 pada jenjang Sekolah Dasar di Kabupaten Subang. Didaktik: Jurnal Ilmiah PGSD STKIP Subang, 6(1), 1-9.

Handarini, O. I., \& Wulandari, S. S. (2020). Pembelajaran daring sebagai upaya study from home (SFH) selama pandemi covid 19. Jurnal Pendidikan Administrasi Perkantoran (JPAP), 8(3), 496-503.

Isgör, I. Y. (2016). Metacognitive skills, academic success and exam anxiety as the predictors of psychological well-being. Journal of Education and Training Studies, 4(9), 35-42.

Lenz, A. S., Gómez Soler, I., Dell'Aquilla, J., \& Uribe, P. M. (2017). Translation and crosscultural adaptation of assessments for use in counseling research. Measurement and Evaluation in Counseling and Development, 50(4), 224-231.

Mackie, D. M., Devos, T., \& Smith, E. R. (2000). Intergroup emotions: Explaining offensive action tendencies in an intergroup context. Journal of Personality and Social Psychology, 79(4), 602.

Nurhidayati, T. (2012). Empati dan munculnya perilaku altruistik pada masa remaja (studi analisis dunia remaja). Edu Islamika, 4(1), 101-123.

Pemerintah Republik Indonesia. (2019). Kementerian kesehatan Republik Indonesia. Riset Kesehatan Dasar.

Permatahati, I. S. (2016). Pengaruh altruistic behaviour terhadap psychological well being pada relawan di sanggar hati kita Tulungagung. Jurnal Psycology Forum UMM, 19-20.

Rushton, J. P., Chrisjohn, R. D., \& Fekken, G. C. (1981). The altruistic personality and the self-report altruism scale. Personality and Individual Differences, 2(4), 293-302.

Ryff, C. D. (1989). Happiness is everything, or is it? Explorations on the meaning of psychological well-being. Journal of Personality and Social Psychology, 57(6), 1069.

Sa'diyah, K. (2020). Pentingnya psychological well being di masa pandemi COVID-19. Jurnal Kariman, 8(02), 221-232.

Sugiyono. (2015). Metode penelitian Pendidikan (Pendekatan kualitatif, kuantitatif, dan R an D). In Grafindo Persada. Grafindo Persada.

Warneken, F., \& Tomasello, M. (2009). The roots of human altruism. British Journal of Psychology, 100(3), 455-471.

Wikanestri, W., \& Prabowo, A. (2015). Psychological well-being pada pelaku wirausaha. Seminar Psikologi Dan Kemanusiaan, 431-439.

Zalsabella, M. P., Darmadi, D., Ningrum, P. P., Yuliarisma, S. A., Safitri, A., Prasetyo, Y. E., \& Nabila, R. F. (2020). Dampak pembelajaran jarak jauh terhadap perasaan tertekan pada siswa kelas tujuh smp saat memahami konsep matematika. Jurnal Review Pendidikan Dan Pengajaran, 3(2), 294-298. 
